\title{
FAKTOR-FAKTOR YANG BERHUBUNGAN DENGAN STATUS GIZI LANSIA DI DESA TANJUNG ANOM WILAYAH KERJA PUSKESMAS PANCUR BATU KABUPATEN DELI SERDANG TAHUN 2017
}

\author{
Endang Junita Sinaga, Hotmarina Lumba Gaol \\ Staff Pengajar STIKes Santa Elisabeth Medan
}

\begin{abstract}
Bacground : Elderly is the life stage of the individual, this phase of this life must be passed by every individual, health conditions at this stage is largely determined by the quality and quantity of nutrient intake. In addition to nutritional intake such as energy and protein intake, physical activity can also contribute to the state of nutritional status of the elderly. Pancur Batu Puskesmas

Goals : Deli Serdang has posyandu elderly in every rural area working area of puskesmas. One of them is an elderly service posyandu unit in Tanjung Anom Village. This study aims to see the factors that affect the nutritional status of elderly in posyandu elderly village tanjum anom.

Method: The research design used is cross sectional study approach. This study has a sample of 38 people, by way of taking purposive sampling. The tools used in data collection are questionnaire and Food Frequency Quetionnaire (FFQ).

Results : The results showed that the majority of women (68.5\%), unfulfilled protein intake $55.3 \%$, 50\% unmet energy intake, and physical activity $73.7 \%$. The results showed that protein intake and physical activity factors were associated with nutritional status of the elderly, as evidenced by $p=0,004$ and 0,003 .

Conclusion: The conclusion of the study was that low intake of protein and energy led to nutritional status of the elderly. It is recommended that family members living with the elderly can balance the intake of protein and energy that is tailored to the type of physical activity of the elderly everyday.
\end{abstract}

\section{PENDAHULUAN}

Angka harapan hidup di Indonesia pada tahun 2000 berada pada angka $64,5 \%$ dan akan meningkat menjadi $66,2 \%$ pada tahun 2006, perkiraan terus meningkat menjadi 67,4\% pada tahin 2010 dan $71,1 \%$ pada tahun 2020. Menurut Kementerian Koordinator Kesejahteraan Rakyat Republik Indonesia tahun 2009 hal tersebut disebabkan oleh populasi penduduk usia lanjut di Indonesia tergolong cepat didunia, tahun 2000 sebesar $7,80 \%$ tahun 2005 mencapai $8,48 \%$ diperkirakan tahun 2010 mencapai $9,77 \%$ dan pada tahun 2020 diperkirakan mencapai $11,3 \%$. Hasil survey yang dilakukan oleh peneliti pada April 2017 didapatkan jumlah lansia di UPT pelayanan social lanjut usia dan anak balita wilayah Deli Serdang Sumatera Utara berjumlah 161 orang dengan 68 orang dan hasil suvey pendahuluan di posyandu lansia Tanjung Anom sebanyak 58 orang yang 
terdaftar tetapi yang rutin mengikuti senamsehari-harinya hanya sekitar 38 orang Peningkatan umur harapan hidup akan timbul beberapa kesenjangan, diantaranya lansia diantaranya kesenjangan psikologis, social dan ekonomi. Usia lanjut merupakan fase kehidupan yang harus dilalui oleh setiap individu, kondisi kesehatan pada tahap ini sangat ditentukan oleh kualitas dan kuantitas asupan gizi. Kurangnya pengetahuan mengenai gizi lanjut usia dan cara pengolahannya yang baik bagi lanjut usia adalah factor yang mempengaruhi status gizi lanjut usia, penyakit-penyakit kronis yang diderita lanjut usia, pengaruh psikologis, kesalahan pola makan serta kurangnya faktor ekonomi/keterbatasan ekonomi keluarga juga menyebabkan kurangnya gizi pada usia lanjut usia.

\section{TUJUAN PENELITIAN}

Tujuan penelitian ini adalah untuk mengidentifikasi faKtor-faktor yang memengaruhi status gizi lansia yang datang berkunjung di posyandu lansia Desa Tanjung Anom pada tahun 2017.

\section{MANFAAT PENELITIAN}

1. Memberikan masukan bagi responden bagaimana status gizi lansia dan memilih jenis asupan yang baik bagi lansia

2. Memberikan masukan kepada pihak keluarga yang mendampingi lansia sehari-hari untuk memilih jenis asupan yang baik bagi lansia

3. Masukan bagi penyenggara posyandu lansia Tanjung Anom dalam meberikan konseling terkait status gizi lansia

4. Bagi kalangan akademik, penelitian ini diharapkan sebagai kontribusi untuk memperkaya khasanah keilmuan tentang kesehatan lansia dimasa yang mendatang.

\section{HIPOTESIS PENELITIAN}

Ada hubungan asupan energy, asupan protein dan aktivitas fisik terap status gizi lansia di Posyandu Lansia Tanjung Anom Tahun 2017.

\section{METODE}

Penelitian ini menggunakan pendektan cross sectional, dengan jumlah sampel 38, pengambilan sampel dilakukan dengan cara purposive sampling yaitu teknik penetapan sampel dengan cara memilih sampel diantara populasi sesuai dengan yang dikehendaki peneliti (Nursalam, 2014). Dengan kriteria yang digunakan adalah pasien yang datang berkunjug ke posyandu lansia, dapat membaca dan menulis dan bersedia menjadi responden.

\section{LOKASI DAN WAKTU PENELITIAN}

Lokasi penelitian dilakukan di Posyandu Lansia yanga di Desa Tanjung Anom Wilayah Kerja Puskesmas Pancur Batu Kabupaten Deli Serdang Tahun 2017, pengukuran dilakukan secara bersamaan pada data variable independen dan dependen.

Waktu penelitian dilakukan sejak bulan April hingga Juni 2017. Tahapan dilakukan mulai dari survei awal, pembuatan proposal penelitian dan sampai penyebaran kuesioner dan pengolahan data.

\section{METODE PENGUMPULAN DATA}

\section{a. Data Primer}

Data primer diperoleh melalui penyebaran kuesioner kepada responden dan mengisi sendiri dengan berpedoman pada kuesioner yang telah disiapkan terlebih dahulu. Sebelumnya kuesioner telah diuji coba terlebih dahulu pada populasi yangmemiliki karakteristik sama.

\section{b. Data Sekunder}

Data sekunder diperoleh dari data posyandu lansia Tanjung Anom meliputi 
jumlah lansia yang didata, jadwal posyandu lansia dan pantauan perkembangan kesehatan lansia. Selain itu diperoleh juga gambaran umum lokasi penelitian.

\section{c. Uji Validitas dan Reliabilitas}

Kelayakan dalam menggunakan instrumen yang akan dipakai untuk penelitian diperlukan uji validitas dan reliabilitas. Validitas berasal dari kata validity yang mempunyai arti sejauh mana ketepatan dan kemaknaan suatu alat ukur dalam mengukur suatu pertanyaan, bahwa instumen dikatakan valid, apabila instumen tersebut dapat mengukur apa yang seharusnya diukur. Demikian juga kuesioner sebagai alat ukur harus mengukur apa yang akan diukur. Uji validitas suatu instumen (dalam kuesioner) dilakukan dengan cara melakukan korelasi antar skor variabel atau item dengan skor total variabel (Corrected Item Total Correlation), jika nilai Corrected item total Correlation > nilai $\mathrm{r}$ tabel $(0,361)$ pada $\alpha 5 \%$ dan $\mathrm{df}=28$, maka dinyatakan valid dan sebaliknya apabila Corrected item total Correlation $<\mathrm{r}_{\mathrm{abel}}$ maka dinyatakan tidak valid ( Hidayat, 2010).

\section{Variabel dan Definisi Operasional} Variabel Penelitian

a. Variabel terikat (dependent variable), yaitu status gizi lansia.

d. Variabel bebas (independent variable), yaitu asupan energy, asupan protein dan aktivitas fisik lansia.

\section{DEFENISI OPERASIONAL}

a. Status gizi lansia adalah hasil pengukuran tinggi badan berdasarkan berat badan lansia yang diperoleh saat pengukuran.

b. Asupan energy lansia adalah jumlah dan jenis asupan sumber energy oleh lansia sehari-hari dan dibandingkan dengan asupan standarsehari-hari usia lansia

c. Asupan protein adalah jumlah, jenis dan sumber protein yang dikonsumsi oleh lansia dan dibandingkan dengan kebutuhan protein lansia.

\section{METODE PENGUKURAN \\ Metode Pengukuran dan Variabel Independen}

Pertanyaan Asupan Energi dan Protein diukur dengan mengisi kuesioner Food Frequency Quetionnaire (FFQ) dan diisi juga di formulir Food Recall 24 Jam. Lansia diberikan kuesioner dan didampingi peneliti dalam mengisi kuesioner, untuk pertanyaan yang kurang dimengerti oleh lansia di arahkan dan dijelaskan oleh peneliti maksud dan tujuan pertanyaan tersebut. Untuk lansia yangdidammpingi oleh anggota keluarga dan dianggap sudah tidak mampu membaca dengan lancer maka peneliti meminta bantuan dari anggota keluarga mengisi dan menanyakan kepada lansia, sehingga informasi yang diharapkan dapat diperoleh dari responden.

\section{METODE ANALISIS DATA}

Tahapan analisis data meliputi :

1. Analisis Univariat ya analisis yang menitik beratkan kepada gambaran ataueskripsi frekuensi dari masingmasing variable independen dan dependen.

2. Analisis bivariate yaitu untuk melihat ada tidaknya hubungan asupan energy, asupan protein dan aktivitas fisik terhadap status gizi lansia.

\section{HASIL}

\section{ANALISIS UNIVARIAT}

1. Jenis Kelamin Responden

Dalam kuesioner dicantumkan kolom jenis kelamin responden, berikut hasil 
distribusi responden berdasarkan jenis kelamin.

Tabel 1. Distribusi Frekuensi Responden Berdasarkan

Jenis Kelamin

\begin{tabular}{ll}
\hline Karakteristik & n \\
\hline Laki-laki & 12 \\
Perempuan & 26 \\
\hline Total & $\mathbf{3 8}$ \\
\hline \multicolumn{2}{l}{ Berdasarkan hasil penelitian mayoritas }
\end{tabular}
lansia adalah perempuan $(68,5 \%)$.

\section{Asupan Protein}

Hasil perhitungan asupan protein diperoleh sebagai berikut :

Tabel 2. Distribusi Responden Protein

\begin{tabular}{llll}
\hline \multicolumn{1}{c}{ Asupan Protein } & n & \% & \\
\hline Terpenuhi & 17 & & 44.7 \\
Tidak Terpenuhi & 21 & & 55,3 \\
\hline Total & $\mathbf{3 8}$ & & $\mathbf{1 0 0 , 0}$ \\
\hline
\end{tabular}

Berdasarkan hasil penelitian berdasarkan asupan protein maka mayoritas lansia tidak terpenuhi asupan protein sebesar $55,3 \%$.

\section{Asupan Energi}

Berdasarkan pengolahan asupan energy diperoleh sebagai berrikut :

Tabel 3. Distribusi Frekuensi Responden Asupan Energi

\begin{tabular}{lll}
\hline $\begin{array}{l}\text { Asupan } \\
\text { Energi }\end{array}$ & $\mathbf{n}$ & $\mathbf{\%}$ \\
\hline $\begin{array}{l}\text { Terpenuhi } \\
\text { Tidak }\end{array}$ & 19 & 50 \\
Terpenuhi & 19 & 50 \\
\hline Total & $\mathbf{3 8}$ & $\mathbf{1 0 0 , 0}$ \\
\hline
\end{tabular}

Berdasarkan penelitian diperoleh bahwa lansia memiliki asupan energi yang terpenuhi sebesar $50 \%$ dan tidak terpenuhi $50 \%$.

\section{Aktivitas Fisik}

Hasil perhitungan aktivitas fisik diperoleh hasil penelitian sebagai berikut :

Tabel 4. Distribusi Frekuensi Responden Aktivitas Fisik

\begin{tabular}{|c|c|c|}
\hline $\begin{array}{l}\text { Aktivitas } \\
\text { Fisik }\end{array}$ & $\mathbf{N}$ & $\%$ \\
\hline 31.5 Tinggi & 10 & 26,3 \\
\hline 68,5 Rendah & 28 & 73,7 \\
\hline 100,0Total & 38 & 100,0 \\
\hline
\end{tabular}
bahwa lansia memiliki aktivitas fisik yang rendah ada sebanyak $73,7 \%$

\section{Status Gizi}

Berdasarkan hasil pengamatan dan pengolah diperoleh stats $g$ lansia sebagai berikut

Tabel 5. Distribusi Frekuensi Responden Status Gizi.

\begin{tabular}{llc}
\hline Status Gizi & $\mathbf{N}$ & $\mathbf{\%}$ \\
\hline Normal & 16 & 42,1 \\
Kurusl & 22 & 57,9 \\
\hline Total & $\mathbf{3 8}$ & $\mathbf{1 0 0 , 0}$ \\
\hline
\end{tabular}

\section{ANALISIS BIVARIAT}

Analisis bivariat dilakukan untuk mengidentifikasi hubungan variabel independen (asupan energy, asupan protein dan aktivitas fisik) dan variabel dependen (status gizi). Hasil analisis menunjukkan ada hubungan yang signifikan antara variabel independen dengan variabel dependen dengan nilai $p<0,05$.

\section{Hubungan Asupan Energi dengan Status Gizi Lansia}

Diperoleh hasil penelitian bahwa lansia status gizinya kurus ada sebanyak 57,9\%, asupan energy protein tidak terpenuhi dan emmiliki status gizi kurus ada sebanyak 13 orang $(61,9 \%)$.

Berdarkan hasil penelitian bahwa lansia yang status gizinya kurus ada sebanyak $57,9 \%$. 
Tabel 6. Distribusi Asupan Protein dengan status gizi lansia di Posyandu Lansia Tanjung Anom

\begin{tabular}{lllllll}
\hline \multirow{2}{*}{$\begin{array}{l}\text { Asupan } \\
\text { Protein }\end{array}$} & \multicolumn{5}{c}{ Status Gizi } \\
\cline { 2 - 7 } & Normal & \multicolumn{2}{c}{ Kurus } & \multicolumn{3}{c}{ Total } \\
\hline & $\mathrm{n}$ & $\%$ & $\mathrm{n}$ & $\%$ & $\mathrm{n}$ & $\%$ \\
\hline Terpenuhi & 8 & 47,1 & 9 & 52.9 & 17 & 100,0 \\
Tidak & 8 & 38,1 & 13 & 61,9 & 21 & 100,0 \\
Terpenuhi & & & & & & \\
\hline Total & 6 & 42,1 & 22 & 57,9 & 38 & 100,0 \\
\hline \multicolumn{5}{c}{$\mathbf{P}=\mathbf{0 , 0 0 4}$} \\
\hline
\end{tabular}

2. Hubungan Asupan Energi dengan Status Gizi Lansia di Posyandu Lansia Tanjung Anom

Dari data diperoleh bahwa status gizi responden yang berada di kurus dan memiliki asupan energy yang terpenuhi ada 19 orang $(68,4 \%)$.

Tabel 7. Distribusi Asupan Energi Protein dengan status gizi lansia di Posyandu Lansia Tanjung Anom

\begin{tabular}{lllllll}
\hline Asupan & \multicolumn{6}{c}{ Status Gizi } \\
\cline { 2 - 7 } Energi & Normal & \multicolumn{2}{l}{ Kurus } & \multicolumn{2}{l}{ Total } \\
\hline & $\mathrm{n}$ & $\%$ & $\mathrm{n}$ & $\%$ & $\mathrm{n}$ & $\%$ \\
\hline Terpenuhi & 6 & 31,6 & 13 & 68,4 & 19 & 100,0 \\
Tidak & 10 & 52,6 & 9 & 47,4 & 19 & 100,0 \\
Terpenuhi & & & & & & \\
\hline Total & $\mathbf{1 6}$ & $\mathbf{4 2 , 1}$ & $\mathbf{2 2}$ & $\mathbf{5 7 , 9}$ & $\mathbf{3 8}$ & $\mathbf{1 0 0 , 0}$ \\
\hline \multicolumn{6}{c}{$\mathbf{p = 0 , 1 8}$} \\
\hline
\end{tabular}

3. Hubungan Aktivitas Fisik dengan Status Gizi Lansia Di Posyandu Lansia Tanjung Anom tahun 2017

Table dibawah ini menunjukkan bahwa responden dengan status gizi kurus dan aktivitas fisik terpenuhi ada 28 orang $(60,7 \%)$.

Tabel 8. Distribusi Asupan Aktivitas Fisik dengan status gizi lansia di Posyandu Lansia Tanjung Anom

\begin{tabular}{lllllll}
\hline \multirow{2}{*}{$\begin{array}{l}\text { Aktivitas } \\
\text { Fisik }\end{array}$} & \multicolumn{6}{c}{ Status Gizi } \\
\cline { 2 - 7 } & Normal & \multicolumn{2}{c}{ Kurus } & \multicolumn{2}{c}{ Total } \\
\hline & $\mathrm{n}$ & $\%$ & $\mathrm{n}$ & $\%$ & $\mathrm{n}$ & $\%$ \\
\hline Terpenuhi & 5 & 50 & 5 & 50 & 10 & 100,0 \\
\cline { 2 - 7 } Tidak & 1 & 39,3 & 17 & 60,7 & 28 & 100,0 \\
\hline
\end{tabular}

\begin{tabular}{lllllll}
\hline Terpenuhi & 1 & & & & \\
\hline Total & $\mathbf{1}$ & $\mathbf{4 2 , 1}$ & $\mathbf{2 2}$ & $\mathbf{5 7 , 9}$ & $\mathbf{3 8}$ & $\mathbf{1 0 0 , 0}$ \\
& $\mathbf{6}$ & & & & & \\
\hline \multicolumn{7}{c}{$\mathbf{P}=\mathbf{0 , 0 0 3}$} \\
\hline
\end{tabular}

Berdasarkan table diatas dan dari hasil pengolahan data mengenai factor-faktor yang memengaruhi status gizi lansia dieperoleh abhwa factor asupan protein dan aktivitas fisik merupakan factor yang mempunyai hubungan dengan status gizi lansia yaitu dengan nilai $(\mathrm{p}=0,004$ dan $\mathrm{p}=0,003$ ).

Hasil dari lansia yang asupan proteinnya yang tidak terpenuhi dan memiliki status gizi kurus sebanyak 61,9\%, asupan energy dengan status gizi kurus sebanyak $68,4 \%$, dan aktivitas fisik yang rendah dengan status gizi kurus atau obesitas sebanyak $60,7 \%$.

Peneliti berasumsi bahwa lansia yang memiliki asupan energy protein yang tidak terpenuhi memiliki status gizi kurus $61,9 \%$, diasumsikan bahwa dengan energi protein yang tidak terpenuhi menyebabkan status gizi yang kurang, Perubahan ini akan mempengaruhi kondisi fisik seseorang dari aspek psikologis, fisiologis maupun lainnya. Sehingga kondisi ini juga berpengaruh terhadap fungsi organ tubuh yang berperan penting dalam mempertahankan dan menciptakan kesehatan yang prima yaitu fungsi organ yang berkaitan dengan makanan dan pencernaannya. Orang yang berusia 70 tahun, kebutuhan gizinya sama dengan saat berumur 50-an. Sayangnya, nafsu makan mereka yang cenderung menurun ditambah lagi dengan berbagai aktivitas semakin membuat penurunan nafsu makan. Oleh karena itu, kebutuhan gizi yang mencukupi sangat penting bagi lansia melalui pengupayaan konsumsi makanan penuh gizi Aktivitas fisik merupakan pergerakan anggota tubuh yang menyebabka pengeluaran tenaga yang sangat penting bagi kesehatan dan mempengaruhi asupan gizi lansia. Aktivitas fisik tersebut berupaolahraga berjalan kaki, berkebun, 
naik turun tangga, angkat beban, membawa belanjaan,mencuci, mengepel lantai (Rianti, 2010). Secara umum kebutuhan gizi para lansia sedikit lebih rendah dari kebutuhan orang dewasa, kondisi ini sebagai konsekuensi penurunan tingkat aktivitas dan metabolism basal tubuh. Oleh karena itu tidak lah heran jika penuaan mengakibatkan penurunan 10-15\%asupan energy.

Secara umum, kebutuhan gizi para lansia sedikit lebih rendah dibanding an tingkat aktivitas dan metabolism basal tubuh para lansia. Metabolisme tubuh lansia mulai menurun setelah usia 50 tahun dan aktivitas fisik pun semakin berkurang.Oleh karena itu, tak mengherankan kalau terjadi penurunan 10-15\% kebutuhan energi. Secara prinsip, kebutuhan gizi pada setiap individu berbeda-beda. Hal ini tergantung pada kondisi kesehatan, berat badan aktual dan tinggi rendahnya tingkat aktivitas fisik seseorang. Disamping itu, angka kecukupan gizi untuk lansia pria dan wanita sedikit berbeda karena adanya perbedaan dalam ukuran dan komposisi tubuh. Berdasarkan penelitian oleh wirakusumah, 2001 menyatakan bahwa kebutuhan unsur gizi tertentu pada lansia mengalami peningktan.

Hal ini disebabkan oleh terjadinya proses degradasi (perusakan) yang berlangsung sangat cepat. Misalnya sebagian besar lansia wanita membutuhkan asupan mineral kalsium sedikit lebih tinggi, tujuannya untuk memperlambat proses kerusakan tulang. Dilain pihak kebutuhan kalori justru mengalami penurunan seiring dengan bertambahnya kankebutuhan gizi di usia dewasa. Kondisi ini merupakan konsekuensi terjadinya penurun usia tidak diimbangi dengan penurunan asupan kalori maka terjadinya obesitas, kemungkinan besar tidak dapat dihindari.

Pemenuhan energy dan protein diperoleh dari pengisian formulir FFQ oleh lansia.

\section{KESIMPULAN}

Faktor asupan protein dan aktivitas fisik memengaruhi status gizi lansia di posyandu Lansia Desa Tanjung Anom.

\section{SARAN}

Anggota keluarga yang tinggal bersama lansia dapat menyeimbangkan asupan protein dan energi yang disesuaikan dengan jenis aktivitas fis lansia sehari-hari

\section{DAFTAR PUSTAKA}

Anna dan Suzanna. (2007). Buku Ajar

Keperawatan Komunitas ; Teori dan

Praktik. Ed.3. Jakarta : EGC

Rianti. (2010).Dikutip tanggal 04 September Http://www.digilib.ums.ac.id. Upload/dokumen/531727052009075 1.pdf

Setysari (2010). Metode penelitian pendidikan dan pengembangan. Jakarta : Kencana

Wirakusumah, E. S. (2001). Menu Sehat Untuk Lanjut Usia. Cet. 1. Jakarta:

Puspa Swarsa Nurachmah, E. (2001). Nutrisi dalam Keperawatan. Jakarta: Agung Seto..

Notoatmodjo, S. (2007). Kesehatan Masyarakat:Ilmu Dan Seni. Jakarta :Rineka Cipta.

Nugroho, W. (2008). Keperawatan Gerontik dan Geratrik. Ed 